\title{
HOLDING YOUR NAME
}

I have stopped numbering my pages.

The calendar curls back against the wall blameless \& white repeating always the same day, the month open, a smooth bed, empty.

Empty the weather passes with your step. I am always opening the door.

The rain comes in, blank, faithful as breath holding your name. I have stopped pretending reason; love is no safe room.

Though the stones are speaking I cannot hear. The wind tightens on my face, the sky broods its dull warnings. Grief that mild bird has turned its head; oh my dear we cannot stop dying. 